\title{
Yahudilikte Salgın Hastalıklarla Mücadele ve Aşılanmaya Karşı Yaklaşımlar: Covid-19 Örneği
}

Fighting Epidemics and Approaches to Vaccination in Judaism:

The Case of Covid-19

\section{Sema Nur Uzun}

Arş. Gör., Artvin Çoruh Üniversitesi İlahiyat Fakültesi

semanur@artvin.edu.tr \& https://orcid.org/0000-0003-0866-3768

\begin{tabular}{|c|c|}
\hline $\begin{array}{l}\text { Makale Türü } \\
\text { Article Type }\end{array}$ & $\begin{array}{l}\text { Araştırma Makalesi } \\
\text { Research Article }\end{array}$ \\
\hline $\begin{array}{l}\text { Geliş Tarihi } \\
\text { Date Received }\end{array}$ & 04.11 .2021 \\
\hline $\begin{array}{l}\text { Kabul Tarihi } \\
\text { Date Accepted }\end{array}$ & 13.12.2021 \\
\hline $\begin{array}{l}\text { Yayın Tarihi } \\
\text { Date Published }\end{array}$ & 31.12 .2021 \\
\hline $\begin{array}{l}\text { Atıf } \\
\text { Citation }\end{array}$ & $\begin{array}{l}\text { Sema Nur Uzun. "Yahudilikte Salgın Hastalıklarla Mücadele ve Aşılanmaya } \\
\text { Karşı Yaklaşımlar: Covid-19 Örneği". Oksident 3/2 (2021): 181-205. }\end{array}$ \\
\hline $\begin{array}{l}\text { İntihal } \\
\text { Plagiarism }\end{array}$ & $\begin{array}{l}\text { Bu makale, Turnitin yazılımı ile taranmış ve intihal tespit edilmemiştir. } \\
\text { This article has been scanned by Turnitin and no plagiarism detected. }\end{array}$ \\
\hline Doi & https://doi.org/10.51490/0ksident.1019240 \\
\hline
\end{tabular}


Öz

2019 yılının sonunda Çin'de ortaya çıkan Covid-19 salginı 2020 yılının başlarında tüm dünyaya yayılmıştır. Hastalı̆ın yayılmasıla mücadelede pek çok ülke, hastalığ taşıyanlara ve hatta tüm nüfusa karantina uygulaması başlatmıştır. 2020 yılının sonunda ise Covid-19 aşlarının üretimine başlanmıştır. Bu gelişmeler tüm dünyada olduğu gibi Yahudi cemaatlerinde de gerek hastalıkla mücadelede izlenmesi gereken yöntemler gerekse kisa sürede onay alan aşlar hakkında tartışmaların ortaya çıkmasına sebebiyet vermiştir. Bu makalede, Yahudilikte genel olarak salgin hastallklar ve özelde Covid-19 salgını karşısinda insan hayatını korumaya yönelik dinî yaklaşımlar sunulmaktadır. Buna göre, Tanah döneminden itibaren günümüze değin Yahudi düşüncesinde, sağlığın korunması ve insan hayatının kutsallığ temel bir ilke olarak yer almıştır. Yahudi hahamlar yüzyllardır, günümüzde yaşanan koronavirüs salginında olduğu gibi, hastayı ve hastalığa yakalanma riski olan diğer kişileri izole etmeyi gerekli görmüşlerdir. Hastalı̆̆n yayılmasını önlemek için dinî ayinlerin askıya alınmasina yönelik talimatlar vermişlerdir. Ayrıca salgin hastalıklara karşı sağlık alanındaki yetkililerin uyarılarına uymayı ve bu doğrultuda onların tausiyeleri gereğince aşı olmayı din̂̂ bir yükümlülük kabul etmişlerdir. Bununla birlikte Yahudilik içinde azınlık olmakla birlikte söz konusu yöntem ve uygulamalara muhalif gruplarm bulunduğu da görülmektedir.

Anahtar Kelimeler: Dinler Tarihi, Yahudilik, Salgın Hastalıklar, Aşı, Covid19.

\section{Abstract}

The Covid-19 epidemic that broke out in China at the end of 2019 has spread worldwide in early 2020. In the struggle with pandemia, many countries imposed quarantines on carriers of the disease and even on entire civilian populations. At the end of 2020, Covid-19 vaccines have been started to administer worldwide. These developments have led to the emergence of discussions about the methods to be followed in the fight against the disease and the vaccines approved in a short time in Jewish communities as well as all over the world. This study offers religious approaches in Judaism to preserve the public's health in general, particularly in the presence of the Covid-19 epidemic. Hereof, the preservation of health and the sanctity of human life have taken place as a basic tenet in Jewish thought from the Tanakh period to the present day. Since the time of the Tanakh, Judaism has viewed the maintenance of health as a religious tenet. For centuries, rabbis have considered it necessary to isolate the diseased person and other individuals who are at the risk of catching the disease, as is the case in the coronavirus epidemic that the world is experiencing now. They have issued orders for the suspension of religious observances to prevent the spread of disease. In addition, they have accepted a religious obligation to comply with health authorities' recommendations against epidemics and be vaccinated by their recommendations. Nevertheless, although they are few, there are groups within Judaism who are opposed to the methods and practices in question.

Keywords: History of Religions, Judaism, Pandemics, Vaccine, Covid-19 


\section{Özet}

2019 yılının sonunda Çin'de ortaya çıkan Covid-19 isimli virüs, hızla bir salgına dönüşerek küresel bir sağlık krizi meydana getirmiştir. Salgınla mücadele etmek üzere pek çok ülke, sınırları kapama, maske takma zorunluluğu, sosyal mesafe ve karantina uygulamaları gibi çeşitli önlemler almıştır. Salgının ortaya çıkmasından yaklaşık bir yıl sonra Covid19'a karşı etkili aşıların bulunmasıyla aşı üretimi başlamıştır. Yaşanan tüm bu gelişmeler insan hayatını psikolojik, fizyolojik, sosyal ve ekonomik yönlerden çeşitli şekillerde etkilemiştir. Alınan önlemler ve getirilen kurallar gerek akademik çevrelerde gerekse halk arasında birbirine zıt görüşlerin ortaya çıkmasına sebep olmuştur. Bir kesim alınan önlemleri ve çıkarılan yasakları desteklerken yaşananları özgürlüklerin kısıtlanması olarak görerek karşı çıkan gruplar da olmuştur. Benzer bölünmenin aşı karşıtlığı ve aşı yanlılığı şeklinde aşılara karşı yaklaşımlarda da yaşandığı görülmektedir.

$\mathrm{Bu}$ makalede, tarih boyunca Yahudiliğin salgın hastalıklarla mücadelede izlediği yollar ve bir salgınla mücadele aracı olarak aşıya karşı yaklaşımı ele alınmaktadır. Yaşanan Covid-19 pandemisi tüm dünyada olduğu gibi Yahudi cemaatlerinde de hastalıkla mücadelede izlenmesi gereken yöntemler konusunda tartışmaları beraberinde getirmiştir. Covid-19 aşısının üretiminin onaylanması da problemleri ortadan kaldırmamış, aksine aşının kısa sürede bulunması ve farklı teknolojilerle üretilmesi yeni tartışmaların ortaya çıkmasına yol açmıştır. Her ne kadar İsrail Devleti aşlama konusunda önde gelen devletlerden biri olsa da İsrail'in yanı sıra diğer ülkelerdeki Yahudi nüfusun içinde de aşı olmayı ve kurallara uymayı reddedenler bulunmaktadır. Yahudilik içinde Ortodoks, Muhafazakâr, Reformist ve Liberal cemaatlerin aşı olma ve

\section{Summary}

The virus named Covid-19, which emerged in China at the end of 2019, quickly turned into an epidemic and created a global health crisis. Many countries have adopted measures such as shutting down borders, obligatory wearing face masks, physical distance, and quarantine practices in the struggle with the epidemic. About a year after the outbreak, vaccine production started with the discovery of effective vaccines against Covid-19. These developments have affected human life from psychological, physiological, social, and economic aspects. The measures taken and the rules introduced have led to opposing views in academic circles and the public. While some support the actions taken and the bans enacted, some groups oppose the events by seeing them as restrictions of freedom. It is seen that a similar division is experienced in approaches to vaccines in the form of anti-vaccine and vaccine bias.

This article addresses the ways Judaism has followed in the fight of epidemics throughout history and its approach to vaccination as a means of handling epidemics. The current Covid-19 pandemic has led to debates in Jewish communities, as so all over the world, about the procedures to be followed in the fight of the epidemic. Approving the production of the Covid19 vaccine did not eliminate the problems; the discovery of the vaccine in a short time and its manufacturing with different technologies led to the emergence of new discussions on the contrary. Although the State of Israel is one of the leading states in vaccination, there are also those among the Jewish population in Israel and other countries who refuse to be vaccinated and to follow the rules. While the 
kurallara uyma konusunda oldukça uyumlu oldukları gözlenirken karşı çıkanların Ultra-Ortodoks Yahudi gruplar içinde yer aldığı görülmektedir.

Yahudi kutsal kitabı Tanah'a dayanan Yahudi hukuk sistemi, yaşanan yeni gelişmelere Yahudi hahamların kutsal metinleri yorumlayarak ve tarihî geleneği takip ederek oluşturdukları fetvalarla cevap vermektedir. Salgın hastalıklarla mücadele Tanah başta olmak üzere pek çok Yahudi dinî metninde yer almaktadır. Tanah'ta ve Yahudi sözlü geleneğinde salgın hastalık, işlenen günahlar sebebiyle Tanrı tarafından gönderilen bir ceza olarak algılanmıştır. Dolayısıyla hastalıklardan kurtulmanın temel yolu, Tanrı'dan af ve bağışlanma dilemek olarak görülmüştür. Bununla birlikte hem Tanah'ta hem de diğer dinî metinlerde bulaşıcı hastalığa yakalananların izole edilmesi gibi hastalığın yayılmasını önleyici talimatlar da yer almaktadır. Yahudilikte kutsal ve Tanrı'nın bir emaneti olarak kabul edilen insan bedenini korumak dinî bir emir addedilmektedir. $\mathrm{Bu}$ nedenle Yahudiler insan sağlığını riske atacak her türlü tehlikeli durumdan kaçınmak ve insan sağlığını korumaya yönelik her türlü eylemi de yapmakla yükümlüdürler. Pikuah nefeş olarak isimlendirilen insan hayatını koruma prensibi kapsamında Yahudi hahamlar, sağllk söz konusu olduğunda tüm dinî emir ve yasakların askıya alınmasını gerekli görmüşlerdir. Buna göre salgın hastalıklar söz konusu olduğunda, salgını önlemek üzere cemaatle ibadet etmenin sinırlandırılmasından Şabat kurallarının ihmaline kadar pek çok konuda yasalar esnetilmiştir. Günümüzde yaşanan Covid19 salgını sürecinde de Yahudi hahamların, cemaatlerine sağlık otoritelerinin talimatları doğrultusunda çözüm ve fetvalar verdiklerini görmekteyiz. Bu bakımdan, salgın hastalıklarla mücadelede Yahudi hahamların merkezi bir role sahip oldukları söylenebilir. Yahudi hahamlar,
Orthodox, Conservative, Reformist and Liberal communities are pretty compatible in getting vaccinated and following the rules, some UltraOrthodox Jewish groups are not.

The Jewish law, based on the Jewish Bible, responds to the new developments with the responsas that rabbis create by interpreting the biblical texts and following the historical tradition. In many Jewish religious texts, especially the Tanakh, the issue of struggle with epidemic diseases is discussed. Both Hebrew Bible and Jewish oral tradition perceive plague as a punishment of God. Therefore, the primary response to the epidemic is to plead for God's mercy and forgiveness for dealing with illness. However, Jewish religious texts contain instructions such as isolating carriers of the disease to prevent the spread of the disease. Judaism considers it a religious precept to protect the human body, which is accepted as sacred and trust of God. For this reason, Jews are obliged to avoid all kinds of dangerous situations that risk human health and take all actions to protect human health. Jewish rabbis considered that all religious orders and prohibitions should be suspended when health is in question as part of the Pikuah Nefesh, the principle of protecting human life. Accordingly, in the case of epidemics, laws have been bent on many issues, from the limitation of worshiping in the congregation to desecrating the Sabbath rules to prevent the epidemic. During the current Covid-19 epidemic, we see that Jewish rabbis offer adjustments and responsas to their communities in line with the instructions of the health authorities. In this respect, it can be said that Jewish rabbis have a central role in the fight epidemics. Jewish rabbis enacted 
sinagogları kapatarak, toplu ibadetleri askıya alarak, hastaları ziyaret, taziye ve düğünlere katılım gibi sosyal görevleri durdurarak bu rollerini yerine getirmişlerdir.

Bununla birlikte, daha çok UltraOrtodoks Yahudilerin içinde yer alan ve gerek ibadetleri kısitlayan yasakları gerekse Covid-19 aşısı olmayı reddeden grupların var olduğu görülmektedir. Bu karşıtlığın dinî, ekonomik ve siyasi yönlerden farklı sebepleri bulunmaktadır. Dinî açıdan, Tanrı'nın doğru olanı (sâlihleri) koruyacağı inancı ve aşırı önlemlerin Tanrı'ya inancın eksikliğini gösterdiği düşüncesi bazı Yahudileri kurallara uymamaya yönlendirmektedir. Hastalığın dinî hükümleri askıya alacak kadar ciddi olmadığının düşünülmesi, dinî ibadetlere seküler kurumların müdahalesini meşru bulmama, ekonomik kaygıların salgını önlemeye yönelik tedbirlere uymaya olanak tanımaması ve Covid-19 aşısının yeterli güvenirliği kazanmaması diğer sebeplerdendir. İlaveten, koronavirüsün kötü niyetli kişiler tarafından yapay olarak üretildiği ve insanlar üzerinde kontrol sağlama amacı taşıdığı şeklindeki inançlar, koronavirüsü sebep göstererek kendilerini belirli eylemleri uygulamaya zorlayanlara karşı gelmeye yöneltmektedir. this role by closing synagogues, suspending communal prayer, and refraining from acts of hospitality such as visiting the sick, comforting mourners, and celebrating weddings all to prevent the spread of Covid-19.

However, it is seen that some people in the Ultra-Orthodox community are against the coronavirus measures and vaccines, and they refuse to be vaccinated. There are many economic, religious, and political reasons for this opposition. From a theological perspective, the belief that God will protect the righteous, and the idea that extreme measures show a lack of faith in God, led some Jews to flout coronavirus rules. Other reasons are that the disease is not thought to be critical enough to suspend religious provisions, that secular institutions do not find the intervention of religious institutions legitimate, and that the Covid-19 vaccine does not gain sufficient reliability. In addition, the belief that malicious people are artificially produced and that it aims to control the masses led them to oppose those who force these people to implement specific actions by showing the coronavirus reason. 


\section{Giriş}

Yahudilik, gelenek ile değişim arasında denge kurmak ve geleneği modern koşullara uygulayabilmek için kişinin muhakeme duygusunu geliştirmek üzere oluşmuş bir fikhî sisteme sahiptir. Bu sistem, bazen modern gelişmelere karşı eski fikir ve yasalara bağlı kalmayı bazen de geleneksel Yahudi yasasını ve düşüncesini modern şartlara uygun hale getirmek üzere değiştirmeyi veya geliştirmeyi gerekli kılmaktadır. Bu amaçla hahamlar bir soru ya da yeni bir problemi kendilerinden önce inşa edilen gelenekteki benzer problemleri gözden geçirerek çözmek durumundadırlar. Gezera şeva ${ }^{1}$ adı verilen bu yöntem, yüzyıllardır Yahudi hukuk kurallarının temelini oluşturmuştur. ${ }^{2}$

Yahudi hukukunun gelenek ve modernite arasındaki dengeyi sağlaması gereken alanlardan biri de tıbbi gelişmelerdir. Bu bağlamda güncel bir vaka olarak koronavirüs pandemisi ve Covid-19 aşısı Yahudi hukukçularının temel meselelerinden birini oluşturmaktadır. Her ne kadar salgın hastalıklar hakkında Tanah'ta bilgi bulmak mümkünse de salgın hastalıklarla mücadeledeki gelişmeler ve salgın hastalıkların tedavisinde aşılanma, Yahudi hukukçuları için yeni birçok tartışmayı beraberinde getirmiştir.

2019 yılının Aralık ayında Çin'in Wuhan eyaletinde, kuşlarda ve memeli hayvanlarda bulunan koronavirüsün bulaşıcı ve öldürücü SarsCov2 (halk dilinde Covid-19) isimli yeni tipinin bir insanda görülmesiyle dünya genelinde bir salgın hastalık ortaya çıkmıştır. Salgının başlamasından bu yana, yeni koronavirüs, hızla ölümcül bir küresel pandemiye dönüşmüştür. İnsan sağllğ̆ için oluşturduğu ciddi tehdide ek olarak Covid-19, sağlık sistemlerinde meydana getirdiği baskı ve sıkışılılık sebebiyle hükümetleri, insanları evlerinde tutma ve işyerlerini kapatma gibi olağanüstü önlemler almak durumunda bırakmıştır. Hem hastalık hem de yol açtığı etkiler insanların fiziksel, psikolojik ve ekonomik zorluklar yaşamasına neden olmuştur. ${ }^{3}$

2020 yılının Aralık ayından itibaren koronavirüse karşı aşı üretiminin başlaması salgının yavaşlaması ve sonlanması için umut olmuş ve insanlar

1 Yahudi dinî hukukunda hüküm koyma yöntemlerinden biri olan gezera şeva, iki farklı olayda kullanılan aynı terime dayanarak başka herhangi bir mantıksal ilişkisi bulunmayan iki olay arasında kıyas yapılmasıyla uygulanmaktadır. Bk. Louis Jacobs \& David Devoran, "Hermeneutics", Encyclopaedia Judaica, ed. Fred Skolnik \& Michael Berenbaum (New York: Thomson Gale, 2007), 9: 26.

2 Elliot N. Dorff, Matters of Life and Death: A Jewish Approach to Modern Medical Ethics (Illinois: Varda Books, 2004), 14.

3 Abid Haleem v.dğr., "Effects of Covid-19 Pandemic in Daily Life", Current Medicine Research and Practice 10/2 (2020): 78-79. 
hızla aşı olmaya yönlendirilmiştir. Ancak bu umut, aşının kısa sürede bulunması ve yeni teknolojilerle üretilmesi gibi faktörler nedeniyle yerini, aşıya karşı oluşan şüphelere bırakmıştır. İsrail Devleti ise bu şüphelere rağmen aşılamada önde gelen devletlerden biri olmuştur. Nitekim 2021 Şubat ayının sonunda İsrail nüfusunun \%50'sinin aşı olduğu bildirilmiştir. ${ }^{4}$

Yahudi tarihinde salgın hastalıklarla ilgili bilgilere Tanah döneminden itibaren rastlanmaktadır. Rabbani dönemde de salgın hastalık durumlarında alınacak önlemler ve uyulması gerekenlere yönelik bilgiler yer almaktadır. Bununla birlikte, Yahudi fıkıhçılar, öncekilerin hükümlerinden yola çıkarak modern bir kavram olan aşı konusunda responsalar (fetvalar) oluşturmuşlardır. Bu makalede, Covid-19 pandemisi özelinde Yahudiliğin salgın hastalıklara ve aşıya karşı yaklaşımları tarihî arka planıyla birlikte ele alınacaktır.

\section{1) Yahudi Kaynaklarında İnsan Sağlığı ve Tıbbi Gelişmelere Yaklaşımlar}

Yahudiliğe göre Tanrı, insan bedeni de dâhil olmak üzere her şeyin sahibidir. ${ }^{5} \mathrm{O}$, insana hayatı süresince kullanması için bedeni emanet etmiştir. Dolayısıyla bedeni en iyi şekilde korumak insanın görevidir. Bu yüzden temizlik kurallarına riayet etmek, yeterince uyumak, egzersiz ve diyet yapmak gibi faaliyetler insanın kaliteli, uzun ve konforlu bir hayat sürebilmesi için önemli olmasının ötesinde Tanrı'ya karşı borç addedilen emirlerdir. Bu sebepledir ki Hillel ${ }^{6}$ (M.Ö. 70-M.S. 10), banyo yapmayı bir mitsva (emir) olarak kabul etmiştir. ${ }^{7}$ Benzer şekilde İbn Meymûn (ö. 1204) da Mişne Tora adlı eserinde insanın, daha uzun ya da daha keyifli bir hayat için değil, Tanrı'ya en iyi şekilde hizmet edebilmek amacıyla sağlığına dikkat etmesi gerektiğini savunmuştur. Ona göre iyi bir sağllk için yerine getirilmesi gereken kurallara uymak fakiri gözetmek gibi diğer emirler kadar önemli bir mitsvadır. ${ }^{8}$

Yahudilikte pikuah nefeş olarak adlandırılan insan hayatını koruma emri, hemen hemen tüm diğer emir ve yükümlülüklerin önüne

4 Dan Williams \& Maayan Lubell, "More than half Israelis receive both COVID-19 vaccine doses", Reuters, erişim: 27.10.2021, https://www.reuters.com/article/ushealth-coronavirus-israel-vaccine-idUSKBN2BHoHO.

5 Bk. Mısır'dan Çıkış 19:5; Tesniye 10:14; Mezmurlar 24:1.

6 Hillel, Herod zamanında Babil'de doğmuş Zugot dönemi Yahudi hahamı, hekim, Yahudi dinî okulunun başkanıdır. Ayrıntılı bilgi için bk. Yehoshua Horowitz, "Hillel”, Encyclopaedia Judaica, ed. Fred Skolnik \& Michael Berenbaum (New York: Thomson Gale, 2007), 9: 108. Midraş, Vayikra Rabba, 34:3.

İbn Meymûn, Mişne Tora, Hilhot De'ot, 3-5. 
geçmektedir. Levililer Kitabı'nda yer alan "Kurallarıma, ilkelerime sarılın. Çünkü onları yerine getiren onlar sayesinde yaşayacaktır"9 pasajından hahamlar, Tanrı'nın emir ve yasaklarına riayet etmenin, insanın ölümüne sebep olmaması gerektiği sonucunu çıkarmışlardır. Buna göre pikuah nefeş prensibi, sağlığı tehlikeye atacak herhangi bir risk ortaya çıktığında, dinî emirlerin askıya alınmasını emretmektedir. Adam öldürme, putperestlik, ensest ilişki ve zina yasakları pikuah nefeş kapsamı dışındadır. Kişi söz konusu suçları işlemektense ölümü tercih etmelidir. ${ }^{10}$ Mesela, bir Yahudi puta tapmakla hayatı arasında seçim yapmaya zorlanırsa, ölümü tercih etmelidir. Bununla birlikte, eğer bir Yahudi yaşamak için Şabat kurallarını ihlal etmek durumunda kalırsa, Şabat kurallarını ihlal etmesi onun üzerine farzdır. ${ }^{11}$ Nitekim Şulhan Aruh'ta ${ }^{12}$ hayat kurtaracak tüm durumların Şabat kurallarını öncelediği ve böyle bir durumda işe koyulmada acele eden kişinin övüleceği yer almaktadır. ${ }^{13}$

Yahudiler kendi hayatlarını kurtarmaları gerektiği gibi başkalarının hayatlarını kurtaracak her türlü davranışı yerine getirmekle ve başkalarına zarar verecek her türlü eylemden de kaçınmakla yükümlüdürler. ${ }^{14}$ Levililer'de yer alan "Komşunun canına zarar vermeyeceksin"15 emrini hahamlar, tehlike altında olan birini kurtarmanın mitsva olduğu şeklinde yorumlamışlardır. ${ }^{16}$ Talmud ve Şulhan Aruh'a dayanarak, insan hayatı için tehlike arz edecek nesnelerin ve hayvanların toplumdan çıkarılması gerektiği sonucuna ulaşılmıştır. Bu da Tesniye Kitabı'ndaki “Yeni bir ev yaparken, dama korkuluk yapacaksın. Öyle ki, biri damdan düşüp ölürse ailen sorumlu sayılmasın"17 pasajından çıkarılmaktadır. Bu durum yalnızca çatıya korkuluk yapılması olarak anlaşılmamış, insanın ölümüne ya da yaralanmasına sebep olacak her türlü tehlikeli durumun ortadan kaldırılması şeklinde yorumlanarak kapsam genişletilmiştir. ${ }^{18}$ Yine Levililer kitabında yer alan "Böyle bir hastalığa yakalanan kişinin giysileri yırtık, saçları dağınık olmalı; kişi ağzını örtüp, 'Kirliyim! Kirliyim!' diye

\footnotetext{
9 Levililer 18:5.

10 Mişna, Sanhedrin, 8:7; Babil Talmudu, Sanhedrin, 74a; İbn Meymûn, Mişne Tora, Yesodei ha-Tora, 5:2.

11 Dorff, Matters of Life and Death: A Jewish Approach to Modern Medical Ethics, 15-16.

12 Şulhan Aruh (Kurulu Masa), 1563 yılında Yosef Karo tarafından kaleme alınmış hukuk kitabıdır. Ayrıntılı bilgi için bk. Yasin Meral, Yahudi Kaynakları Işığında Yahudilik (İstanbul: Milel ve Nihal Yayınları, 2021), 178-179.

Yosef Karo, Şulhan Aruh, Ora Hayim, 329.

Babil Talmudu, Berahot, 32b.

Levililer 19:16.

Midraş, Sifra, Kedoşim, 4.

Yasa'nın Tekrarı 22:8.

İbn Meymûn, Mişne Tora, Rotseah u-Şmirat Nefeş, 11-13.
} 
bağırmalı. Hastalığı devam ettiği sürece kirli sayılacaktır, çünkü kirlenmiştir. Halktan uzak, ordugâhın dışında yaşamalıdır"19 pasajında, bulaşıcı bir hastalığa yakalananların, hastalığı başkalarına bulaştırmamaları için hastalıklarını gizlememeleri ve karantinaya alınmaları istenmektedir. ${ }^{20}$ Ayrıca "kendine dikkat et ve ruhunu koru (hişamer leha u-şemor nefşeha)" ${ }^{21}$ emri gereğince tehlikeli yiyeceklerden, faaliyetlerden ve durumlardan kaçınmak her birey için yükümlülük olarak görülmüştür. ${ }^{22}$

Mişna Yoma'da, hamile bir kadının Yom Kipur'da oruçluyken yemek kokusu aldığında, kendini iyi hissedene kadar yemek yemesinin sağlanması gerektiği ifade edilmektedir. Yine hasta olan kişinin, uzmanların talimatına göre beslenmesi gerektiği, eğer uzman biri yoksa hastanın kendi istediği miktarda ve şekilde beslenmesinin sağlanması tavsiye edilmektedir. Hatta açlıktan gözü dönen bir kişinin gözlerine fer gelinceye kadar murdar yiyeceklerden yemesine izin verilmiştir. Ayrıca Rabbi Matia ben Haraş, boğazı ağrıyan kişinin Şabat'ta ağzına ilaç konabileceğini çünkü bu durumun insan hayatı için bir tehlike olabileceğini ve insan hayatına yönelik her potansiyel tehlikenin Şabat'tan üstün olduğunu ifade etmektedir. $^{23}$

Ayrıca sağlık hizmeti sunma, sadece hekimlerden beklenen ferdi bir görev olarak görülmemekte, her toplumun cemaatine sağlaması gereken zorunlu bir hizmet kabul edilmektedir. Talmud'da bir hahamın bir yere yerleşebilmesi için o yerde hizmet veren bir hekimin bulunması temel koşullardan biri olarak zikredilmektedir. ${ }^{24}$ Yahudi âlimi olmasının yanı sıra iyi bir hekim olarak da bilinen İbn Meymûn, veba sırasında yalnızca dua etmek ve oruç tutmak gibi dinî uygulamaları yeterli görmemiştir. Sadece hastalığı tedavi etmenin değil, aynı zamanda hastalığa yakalanmamak için gerekli önlemlerin alınmasının da bir yükümlülük olduğunu vurgulamıştır. ${ }^{25}$ Görüldüğü üzere Yahudi geleneğinde kişinin kendi sağlığını koruyacak şekilde yaşaması, başkalarının sağlığını tehdit edecek eylemlerden kaçınması ve hastalık durumunda iyileşmek için tedavi yolları araması, Tanrı'ya karşı bir borç olarak görülmekte ve dinî ödev addedilmektedir.

\footnotetext{
19 Levililer 13:4,5-4,6.

20 İsmail Taşpınar, "Yahudilik ve Hıristiyanlıkta Tıp”, Sağlık Düşüncesi ve Tıp Kültürü, 41 (2016- 2017): 36-41.

21 Yasa'nin Tekrarı 4:9.

22 Asher Bush, "Vaccination in Halakhah and in Practice in the Orthodox Jewish Community", Hakirah, 13 (2012): 188.

Mişna, Yoma, 8:5-6.

Babil Talmudu, Sanhedrin, $17 \mathrm{~b}$.

İbn Meymûn, Mişne Tora, Hilhot De`ot, 4.
} 


\section{2) Salgın Hastalıklarla Mücadele}

Tanah'a bakıldığında, toplumda ne zaman bir salgın hastalık yaşansa, toplumun, bu hastalı̆̆g Tanrı'nın gönderdiği bir ceza olarak algıladığ görülmektedir. $\mathrm{Bu}$ hastalıklar sebebiyle kimin öleceğine ve kimin iyileşeceğine karar veren de Tanrı'dır: “'Ben, Tanrınız Rab’bin sözünü dikkatle dinler, gözümde doğru olanı yapar, buyruklarıma kulak verir, bütün kurallarıma uyarsanız, Mısırlılara verdiğim hastalıkların hiçbirini size vermeyeceğim' dedi, 'Çünkü size şifa veren Rab benim.." ${ }^{26}$ Dolayısıyla bu pasajda ifade edildiği üzere, Tanrı kendisine itaat etmeyen insanları hastalıklarla cezalandırmaktadır. Böyle bir cezalandırmadan dolayı yaşanan salgın ya da felaket durumunda, cezalandırmadan kurtulmak için yapılması gereken şey de yine Tanah'ta bildirilmektedir. Çölde Sayım Kitabı'nda, Musa ve Harun'a isyan eden Korah'ın isyanı sebebiyle İsrailoğulları arasında bir salgın baş göstermiş ve binlerce İsrailli ölmüştür. Korah'ın günahı sebebiyle Tanrı'nın onları cezalandırdığını anlayan Musa'nın emri üzerine, Harun'un Tanrı'nın gazabını yatıştıran buhur sunmasının ardından salgın son bulmuştur. ${ }^{27}$ Dolayısıyla bu pasaja göre, salgın durumlarında yapılması gereken en önemli şey, Tanrı'dan af ve bağışlanma dilemektir.

M.S. 70 yılında II. Mabed'in yıkılmasından sonra Tanrı'nın salgınları kontrol ettiğine ve salgınların Tanrı'nın gönderdiği bir ceza olduğuna dair inanç devam etmiştir. ${ }^{28}$ Bununla birlikte, salgınlarla mücadelede yeni yöntemler de geliştirilmiştir. ${ }^{29}$ Salgın hastalıklara karşı yapılması gerekenler Talmud döneminden itibaren Yahudi kaynaklarında yer almaya başlamıştır. Talmud'da bir şehirde salgın başladığında kişinin o şehri terk etmesi gerektiği belirtilmiştir. ${ }^{30}$ Poskim (yasa koyucular) de salgının başlangıcında kişilerin şehri terk etmelerini tavsiye etmektedir. Ancak salgın, kişi şehri terk etmeden önce yayılmışsa şehri terk etmeyip evde kalmanın evla olduğu belirtilmiştir. ${ }^{31}$ Bu doğrultuda Covid-19 pandemisi

26 Misır'dan Çıkış 15:26.

27 “Sonra Musa Harun'a, 'Buhurdanını alıp içine sunaktan ateş koy, üstüne de buhur koy' dedi, 'Günahlarını bağışlatmak için hemen topluluğa git. Çünkü RAB öfkesini yağdırdı. Öldürücü hastalık başladı.’ Harun Musa'nın dediğini yaparak buhurdanını alıp topluluğun ortasına koştu. Halkın arasında öldürücü hastalık başlamıştı. Harun buhur sunarak topluluğun günahını bağışlattı. O ölülerle dirilerin arasında durunca, öldürücü hastalık da dindi." (Çölde Sayım 16:45-49). Bk. Babil Talmudu, Arahin, 15a; Ta'anit, 21b.

Elon Gilad, "How Judaism Handled Epidemics Down the Ages", Haaretz, erişim: 21.10.2021, https://www.haaretz.com/science-and-health/.premium-coronavirusepidemic-history-jewish-1.8724,14,1.

31 Yaakov Levi Moelin, Şe'elot u-Teşuvot Maharil (Krakow, 1881), blm. 41. 
için de Ortodoks hahamlar, sağlık görevlilerinin talimatları uyarınca evlerde kalınması gerektiğini vurgulamışlardır. ${ }^{32}$

Bir salgın sırasında yapılması gereken eylemler ve uyulması gereken kurallarla ilgili olarak kaleme alınan en kapsamlı ve derinlemesine talimatlar, Polonya'da kolera salgını yaşandığı sırada orada görev yapmakta olan Rabbi Akiva Eiger tarafından düzenlenmiştir. 19. yüzyılın başlarında seçkin bir Talmud bilgini, etkili bir halaha otoritesi ve Avrupa Yahudiliğinin önde gelen lideri olan Rabbi Eiger (1761-1837), hastalığın yayılmasını önlemeye büyük ölçüde yardımcı olan enfeksiyon alanlarını izole etmek için talimatlar vererek bir dizi düzenleme başlatmıştır. Halka açı yerlerde hijyenin sağlanmasından ve halkı bilinçlendirmekten sorumlu bir komite atamıştır. ${ }^{33} \mathrm{O}$, salgın süresince dinî gelenekleri ve yasaları askıya almaktan çekinmemiştir.

İyi bilindiği gibi, Yahudi hukukunda on üç yaşını doldurmuş en az on yetişkin Yahudi erkeğin (minyan), belirli duaları okumak gibi emirleri yerine getirmek üzere günde üç defa bir araya gelmesi gerekir. Rabbi Eiger, o zaman bile hastalığın yayılmasında çok ciddi tehlike arz eden kalabalığın toplanmasını önlemek için, alan dar olduğunda ve insanların kalabalık olma ihtimalinin yüksek olduğu durumlarda, sinagogda yeterli alan olmasına rağmen cemaatin küçük gruplar hâlinde dua etmesi gerektiğini belirtmiştir. ${ }^{34}$ Ayrıca salgın döneminde insanların dikkat etmesi gereken birtakım tavsiyelerde bulunmuştur. Buna göre, yaşanan çevreyi temiz tutmak, her hafta temiz kıyafet giymek, endişe ve üzüntüden uzak durmak, gece yürüyüşü yerine gün ışığında ve açık arazilerde yürüyüş yapmak, hardal tohumu tüketmek, her gün elleri ve yüzü yıkamayı alışkanlık edinmek, yerleri sirke ve gül suyuyla temizlemek dikkat çeken tavsiyelerdendir. ${ }^{35}$ Covid-19 pandemisi kapsamında günümüz Yahudi hahamlarının de benzer tavsiyelerde bulundukları ve bu süreçte

32 Rabbi Avraham Steinberg, "The Coronavirus Pandemic: Historical, Medical, and Halakhic Perspectives”, Corona Guidance: Religious Norms for Navigating the COVID-19 Pandemic, 7, erişim: 15.10.2021,

https://web.colby.edu/coronaguidance/files/2020/06/Coronaviruspandemic_historical-medical-and-halakhic-perspectives_2nd-edition_Steinberg.pdf. Akiva Eiger v.dğr., Sefer Igrot Sofrim: Mikhteve Kodesh Mi-Ge' one ha-Dor (Viyana, 1929), mektup 29.

34 Eiger v.dğr., Sefer Igrot Sofrim: Mikhteve Kodesh Mi-Ge' one ha-Dor, md. mektup 29; Andrej Simcha Neuschloss, Rabbi Akiba Eger: His Life and Times (Philadelphia: The Dropsie College for Hebrew and Cognate Learning, 1956), 123-125; Adam Reinherz, "Rabbi's Pandemic Edicts Save Lives - During the Cholera Crisis of 1831", Pittsburgh Jewish Chronicle, erişim: 30.10.2021,

https://iewishchronicle.timesofisrael.com/rabbis-pandemic-edicts-save-livesduring-the-cholera-crisis-of-1831/. 
cemaatlerine rehberlik etmeye çalıştıkları görülmektedir. Birçok haham, Yahudilerin pandemi sürecinde yetkililer tarafından belirlenen kurallara uymaları gerektiğini vurgulamış, bu kurallara riayet etmenin Tanrı'ya ve diğer insanlara karşı bir vazife ve yaşadıkları devlete karşı da önemli bir ödev olduğunu ifade etmiştir. Bilindiği üzere, Yahudilikte yer alan "Dina d'malkuta dina" ${ }^{36}$ prensibi gereği Yahudilerin yaşadıkları ülkenin sivil yasalarına uymaları dinî bir emirdir. ${ }^{37} \mathrm{Bu}$ nedenle Yahudi cemaatleri, Covid-19'un yayılmasını önlemek amacıyla sinagogları kapatarak ve konukseverlikten, hastaları ziyaret etmekten, yaşlıları teselli etmekten ve düğünleri kutlamaktan feragat ederek dinî emirleri askıya almışlardır.

İsrail Hahamlar Başkanlığı (Chief Rabbis of Israel), koronavirüsü önleme amacıyla Sağllk Bakanlığı'nın sunduğu önerilere uyulmasının dinî bir yükümlülük olduğunu ifade etmiştir. Buna göre, Sağlık Bakanlığı'nın önerileri dinî emirdir, zira sağllkla ilgili her talimat aynı zamanda dinî bir yasadır. Mesela, İsrail Sefarad Yahudileri hahambaşısı Yitshak Yosef, koronavirüs nedeniyle Şabat esnasında telefonların açık tutulmasını, zira herhangi bir hayat kurtarıcı bilgi ya da haberin ulaşabileceğini ifade etmiştir. ${ }^{38}$ Bunun yanı sıra, İngiltere, ABD, Avustralya ve Fas gibi pek çok Yahudi cemaatinde sinagoglar, tehlike geçinceye kadar kapatılmış ve dinî faaliyetler askıya alınmıştır. Sefarad ve Reform Yahudi gruplarında on kişilik fiziksel bir minyana sanal olarak katılmanın mümkün olduğuna dair fetvalar verilmiştir. ${ }^{39}$

Covid-19'la mücadelede İsrail medyasında Ultra-Ortodoks (Haredi) grupların pek başarı gösteremediğine, sosyal mesafe ve kurallara uymadığına yönelik haberler çıkmıştır. ${ }^{40}$ Yahudilik Halk Sağlığı

36 Babil Talmudu, Bava Batra, 55a.

37 Michael Walzer v.dğr., The Jewish Political Tradition (New Haven: Yale University Press, 2000), 1: 431-434.

38 RAA Igud HaRabbonim, "Rav Yitzchak Yosef: Coronavirus and Cellphones on Shabbos", erişim: 20.10.2021, https://rabbinicalalliance.org/2020/03/18/ravyitzchak-yosef-coronavirus-and-cellphones-on-shabbos/.

39 Rabbi Joshua Heller, “Counting a Minyan via Video Conference”, erişim: 21.10.2021, https://www.rabbinicalassembly.org/sites/default/files/2021-07/heller\%20-

\%20zoom\%20minyan.pdf; Central Conference of American Rabbis, "Virtual Minyan in Time of COVID-19 Emergency", erişim: 21.10.2021, https://www.ccarnet.org/ccarresponsa/5780-2/; Rabbi David Golinkin, "Ten Brief Responsa/Halakhic Reactions to the Corona Crisis", Corona Guidance: Religious Norms for Navigating the COVID-19 Pandemic, erişim: 21.10.2021, https://web.colby.edu/coronaguidance/2020/04/o2/golinkin-ten-responsa/.

40 David M. Halbfinger, "Virus Soars Among Ultra-Orthodox Jews as Many Flout Israel's Rules", The New York Times, erişim: 20.10.2021, https://www.nytimes.com/2020/03/30/world/middleeast/coronavirus-israel-casesorthodox.html; Toi Staff, “Around Half of Israelis Hospitalized with Coronavirus Are Ultra-Orthodox - Tv”, The Times of Israel, erişim: 20.10.2021, 
Raporlarına göre ABD'deki Ortodoks Yahudiler içinde özellikle Hasidi gruplar, diğer etnik ya da dinî gruplara nazaran Covid-19 kaynaklı ölüm oranlarını artırmış olabilir. ${ }^{41}$ Ortodoks topluluklar birbirleriyle etkileşime değer veren, cemaati önemseyen, ailevi ve sosyal bağları kuvvetli bir yapıya sahip olduklarından birbirlerinden izole şekilde evlerinde durmalarına dair emirlerin uygulanmasında daha başarısız olmuşlardır. Nitekim Ortodoks Yahudiler, günde üç kez ibadet amacıyla, Tevrat ve Talmud çalışmaları yapmak üzere, dinî bayramlar ile düğün ve cenaze gibi törenlerde düzenli olarak bir araya gelmektedir. Aslında normal şartlarda bu tür sosyal ilişkiler din ve sağllk açısından olumlu bir etken olarak kabul edilmekteyken pandemi söz konusu olduğunda büyük bir risk oluşturmaktadır. $^{42}$ Bunun yanı sıra Ultra-Ortodoks Yahudiler, geniş ailelere ve daha düşük ekonomik gelire sahip oldukları ve teknoloji ile aralarına mesafe koyduklarından pandeminin getirdiği olumsuzluklardan daha fazla etkilenmişlerdir. ${ }^{43}$ Mesela, Covid-19'la ilgili gelişmelerin, kuralların ve tavsiyelerin internet ve medya aracılığıyla yayılması sebebiyle, söz konusu yayın organları ile aralarında mesafe olan UltraOrtodokslar bu bilgilere erişememiş ya da geç erişmişlerdir. Yine bu durum sebebiyle, Ultra-Ortodokslar kendi içlerinde de hızlı bir şekilde iletişim kuramamışlar ve birbirlerini haberdar edememişlerdir. Hatta öyle ki, Kudüs'te, çoğunlukla Ultra-Ortodoks Yahudilerin -kısmen izole bir şekildeyaşadığı Mea Şe‘arim bölgesinde, virüsün varlığından hiç haberi olmayanların bulunduğundan bahsedilmektedir. ${ }^{44} \mathrm{Bu}$ bakımdan, UltraOrtodoks Yahudilerin Covid-19 pandemisi kapsamında çıkarılan yasalara uymamalarının ve Covid-19 kaynaklı hastalık ve ölümlerin en çok bu gruplar içinden çıkmasının sebeplerinden biri hükümetin bilgilendirme konusunda yetersiz kalmasıdır.

https://www.timesofisrael.com/around-half-of-israelis-hospitalized-with-

coronavirus-are-ultra-orthodox-tv/; Shira Hanau, "Hundreds Pack Brooklyn Study Hall and Street for Hasidic Rabbi's Funeral", The Times of Israel, 2021.

41 Steven Pirutinsky v.dğr., "COVID-19, Mental Health, and Religious Coping Among American Orthodox Jews", Journal of Religion and Health 59/5 (2020): 2289.

42 Pirutinsky v.dğr., "COVID-19, Mental Health, and Religious Coping Among American Orthodox Jews”, 2289.

43 İsrail'deki Ultra-Ortodoks kadınlar arasındaki doğurganlık oranı genel Yahudi kadın nüfusuna oranla daha yüksektir. Ultra-Ortodoks Yahudiler arasında internet kullanım oranı ise nispeten düşüktür. Bk. Ariela Popper-Giveon \& Yael Keshet, "NonVaccination Stage Model (NVST): The Decision-Making Process Among Israeli UltraOrthodox Jewish Parents”, Health, Mayis 2021, 4.

44 Kobi Nachshoni, "Rabbi Kanievsky, a Second Before the Instruction About Holding Studies for Haredim: 'I Haven't Heard About Any Pandemic.', Ynet, erişim: 20.11.2021, https://www.ynet.co.il/articles/o, 734,0,L-5698287,00.html. 
Hükümet yetkililerince doğrudan bilgilendirme yapılmaması, Harediler arasında farklı kaynaklardan gelen bilgi kirliliğine ve salgının düzmece/yapay olduğu ya da Yahudilerin hayat tarzlarına müdahale amacı taşıdığı şeklinde ortaya atılan komplo teorilerinin yayılmasına neden olmuştur. ${ }^{45} \mathrm{Bu}$ durum tabii olarak, onların hükümetin zorunlu tuttuğu kurallara karşı çıkmaları ile neticelenmiştir. Salgının ilk dalgasından (Şubat-Mayıs 2020) itibaren Ultra-Ortodoksların çoğunlukta olduğu Kudüs'teki Mea Şe 'arim ve Tel Aviv yakınlarındaki Bney Brak bölgelerinde, okulların kapatılmaması, sosyal mesafe kurallarına riayet edilmemesi, Fısıh Bayramı'nın toplu bir şekilde kutlanması ve düğün ve cenaze törenlerinin gerçekleştirilmesi gibi pek çok olay medyada yer almıştır. ${ }^{46}$ Polisin kalabalıklara müdahalesi sebebiyle halk ve polis arasında çatışmalar meydana gelmiştir. ${ }^{47}$ Yukarıda yer verilen söz konusu sebeplerle UltraOrtodoks Yahudiler, Modern Yahudi cemaatlerine nazaran yeni hayat şartlarına uyum göstermede daha geride kalmışlardır.

2020 yılının Mart ayında hükümetin okulların yüz yüze eğitimi durdurması çağrısına karşın Hasidi lider Rabbi Hayim Kanievsky ve pek çok diğer Ultra-Ortodoks haham cemaatlerine okulları ve yeşivalarını açık tutmaları yönünde bildiride bulunmuştur. Kanievtsky, "Tevrat çalışmak korur ve kurtarır"48 şeklindeki Talmud pasajina atıfta bulunarak yeşivaların kapatılmaması gerektiğini savunmuştur. Ayrıca o, salgının insanların günahlarına bir ceza olduğunu ve salgının durması için herkesin tövbe etmesi gerektiğini ifade etmiştir. ${ }^{49}$ Pek çok Modern Ortodoks Yahudi cemaati, üyelerine çevrimiçi ibadet imkânı sunarken Haredi gruplarda bu sayı yok denecek kadar azdır. ${ }^{50}$ Bununla birlikte Ultra-Ortodoks Yahudilik,

45 Marik Shtern \& Hani Vayzer, Keeping Our (social) Distance? The Coronavirus Pandemic and the Relationships Between the Various Groups in Jerusalem, çev. Gilah KahnHoffman (Jerusalem: The Jerusalem Institute for Policy Research, 2021), 30.

Patrick Kingsley, “How Many Funerals Will Come Out of This One?", The New York Times, erişim: 20.11.2021,

nytimes.com/interactive/2021/02/17/world/middleeast/israel-orthodox-jews-

haredim.html.

47 A. Schternbach \& Y. Eli, "Riots in Mea Shearim: A Girl Was Hurt by a Stun Grenade Thrown by a Policeman.", Channel 13 News, erişim: 20.11.2021,

https://13news.co.il/item/news/domestic/crime-law/crime/jerusalem-corona$104.6659 /$.

48 Babil Talmudu, Sota, 21a.

49 Rabbi Yitz Greenberg, "Coronavirus Is A Wake Up Call For Ultra-Orthodox Jews", Jewish Journal, erişim: 22.10.2021,

https://jewishjournal.com/commentary/opinion/314354/coronavirus-is-a-wake-upcall-for-ultra-orthodox-jews/. 
monolitik bir yapı olmadığından içlerinde koronavirüse karşı alınacak tedbirlere sıkı bir titizlikle uyanlar da bulunmaktadır. Bazı Haredi liderler, cemaatlerini maske takmaları, aşı olmaları ve devletin uygulanmasını istediği diğer kurallara riayet etmeleri konusunda uyarmışlardır. Haredi Halkla İlişkiler Enstitüsü (Haredi Institute for Public Affairs) başkanı ve Haredi dergisi Mişpaha'nın (Mishpacha) yayıncısı Eli Paley, Rabbi Kanievtsky'nin açıklamalarından yaşadığı hayal kırıklığını ifade ederek Haredi grupların okulları açı tutmalarını, kalabalık düğün ve cenaze törenleri düzenlemelerini kınamakta ve bu grupların tüm Haredileri temsil etmediğini dile getirmektedir. ${ }^{51}$ Hastalığı Tanrı tarafından gönderilen bir ceza olarak gören, tövbe ve ibadetle salgının sona ereceğine inanarak kurallara uymayan Haredi gruplar Modern Ortodoks cemaatlerce de eleştirilmektedir..$^{52}$

\section{3) Yahudilik ve Aşı}

Bulaşıcı hastalık kavramı, ilk dönemlerden itibaren Yahudi literatürünün gündemindeyken, aşlar konusu ancak 18. yüzyılın sonlarında tartışmaya açılmıştır. Aşı, hastalıklara karşı bağışıklık kazandırmak amacıyla insan ve hayvanlarda hastalığa sebep olan virüs, bakteri vb. mikropların güçlerinin zayıflatılmasıyla oluşturulan bir üründür. Aşılar sayesinde enfeksiyonlara karşı bağışılklı oluşturularak toplum salginlardan korunmakta ve enfeksiyon kaynaklı hastalık, sakatlık ve ölümler engellenmektedir. ${ }^{53}$ Edward Jenner (1749-1823), çiçek hastalığıyla mücadele için 1796 'da ilk modern aşıyı üretmiştir. Bunu, çok daha iyi huylu bir hastalık olan sığır çiçeği hastalığını bir kişiye aşılayarak yapmış ve böylece çiçek hastalığına karşı bağışıklık oluşturmuştur. Çoğu zaman hastalığa karşı etkili sonuç veren bu aşı, yaklaşık \%0.5-2 arası ölüm oranına sahiptir. ${ }^{54}$

Suçiçeği hastalığı için ilk kez aşı bulunduğu dönemde, daha önce sağllklı bir insana hastalık sebebi olan bir ilaç verilerek iyileştirme tekniği kullanılmadığından bu tedavi şekli büyük tartışmalara sebep olmuştur.

51 Shahar Ilan, "Eli Paley Interviewed in Calcalist, January 28, 2021", The Haredi Institute for Public Affairs, erişim: 22.10.2021, https://machon.org.il/en/eli-paleyinterviewed-in-calcalist/.

Shaul Magid, "COVID-19, Haredi Jewry, and 'Magical' Thinking”, Tablet, erişim: 21.10.2021,

https://www.tabletmag.com/sections/belief/articles/covid-haredi-magicalthinking.

53 Çiğdem Kader, “Aşı Karşıtlığı: Aşı Kararsızlı̆̆ı ve Aşı Reddi ”, Eskişehir Türk Dünyası Uygulama ve Araştırma Merkezi Halk Sağhı̆ı Dergisi 4/3 (2019): 378. 
Yahudiler için de durum bir dilemmaya dönüşmüştür. Zira Yahudi literatüründe yar alan kaynaklar doktorlara hastayı iyileştirme yetkisi vermektedir. Ancak bu yetki, doktorların sağllklı bir insana, daha kötü bir hastalıktan korumak amacıyla da olsa, hastalığa neden olan bir maddeyi enjekte etmesine izin verir mi? 18 ve 19. yüzyllarda Yahudi âlimler bu durumu gündemlerinde tutmuşlardır. Bu âlimler arasında aşı olmanın bir gereklilik ve dinî yükümlülük olduğunu savunanlar olduğu gibi aşı olmaya karşı çıkan ya da aşı olmayı bir zorunluluk olarak görmeyenler de ortaya çıkmıştır. Hem aşı olmanın zorunluluğunu savunan hem de aşı olunmasını tavsiye etmeyen hahamlar görüşlerini Tanah'a ve Talmud'a dayandırmaya çalışmışlardır. Âlimlerin pek çoğu, çatıya korkuluk yapılmasını emreden pasaja ${ }^{55}$ ve onun yorumlarına dayanarak ölüme ya da yaralanmaya yol açan tehlikeli durumların ortadan kaldırılmasının ve gerekli önemlerin alınmasının dinî bir emir olduğunu savunmuşlardır. Buna göre aşı olunması da meydana gelecek ölümleri engelleyecek bir önlem olduğundan aşı olmamak, söz konusu emri göz ardı etmektir. Bununla birlikte, aşının sebep olabileceği zararlar ve koruyuculuğu üzerindeki şüpheler, aşı karşıtı görüşlerin ortaya çıkmasına neden olmuştur. Aşı sebebiyle ölme ihtimali her ne kadar suçiçeğinden ölme ihtimaline kıyasla çok daha düşükse de bazı âlimler aşının verebileceği zararları göz önünde bulundurarak insanların sağlıklarını riske atmayı doğru bulmamışlardır. Diğer bir deyişle aşı olduğu için bir kişinin hayatını kaybetme riski varsa bu durumda daha çok kişiyi kurtarmak için bu riski almaya onay vermemişlerdir. Ancak Rabbi Yisrael Lipstchitz, Mişna'yı şerh ettiği eseri Tiferet Yisrael'de, bu soruyu ele alarak tehlikeli olduğu halde bu aşının yapılmasının caiz olup olmadığını tartışmakta ve aşı yaptırmamanın tehlikesi, aşılamanın doğuracağı tehlikeden çok daha büyük olduğu için aşı yaptırmanın caiz olduğu sonucuna varmaktadır. ${ }^{56}$ Yine Sefarad Rabbi İşmael ben Abraham haKohen (1723-1811), Praglı Rabbi Eleazar Fleckels (1754-1826) ve Rabbi Mordecai Benet çiçek aşısına onay veren ilk hahamlardan olmuşlardır. ${ }^{57}$

1785 'te Londra'nın hahamlarından Rav Avraham Hamburg -Nanzig olarak da bilinir- Ale Terufa (Şifa Yaprağı) adlı kitabında aşı konusunu ve bu konuyla ilgili tartışmaları değerlendirmiştir. $O$, daha önce uygulanmayan ve bilinmeyen bir tedavi yöntemi olması itibarıyla aşının dinî açıdan caiz olup olmadığını sorgulamıştır. İki çocuğunu çiçek hastalığı sebebiyle kaybeden Nanzig, eserinde rabbani yorumlara, tıbbi bilgilere ve hastalıkla ilgili açıklamalara yer vermiştir. O, aşı uygulamasıyla hasta olmayan bir

Tesniye 22:8.

Yisrael Lipstchitz, Tiferet Yisrael, çev. Sefaria Community (Vilna, 1913).

J. David Bleich, "Survey of Recent Halakhic Periodical Literature", Tradition: A Journal of Orthodox Jewish Thought 48/2/3 (2015): 45. 
kişiye, hastalığa sebep olacak maddelerin enjekte edilmesinin kişinin sağlığını tehlikeye attığını ve dahası aşının, yeni ve denenmemiş bir yöntem olmasının da ayrı bir risk oluşturduğunu ifade ederek bu konuların hem Yahudiler hem de Yahudi olmayanlar için tereddüt oluşturduğunu belirtmektedir. Ancak o dönemde çiçek hastalığından dolayı Avrupa'da 4,00.00o kişinin öldüğü de vakıadır. ${ }^{58}$ Hastalığın öldürücü etkisinin bu denli yüksek olması, Nanzig'i, aşının birkaç kişi üzerinde oluşturabileceği yan etkiden/riskten daha çok faydası olduğu sonucuna ulaştırmıştır. ${ }^{59}$

Covid-19 aşısı ile ilgili hukuki tartışmalara bakıldığında Yahudi hukukçuların geçmişteki aşı tartışmalarıyla bağlantılı olarak konuyu değerlendirdikleri görülmektedir. Covid-19 aşısıyla ilgili ilk tartışılan konu, aşının güvenilirliği ve hastalığa karşı etkililik oranının risk almaya değer düzeyde olup olmadığıdır. Amerikan Gıda ve İlaç Dairesi (U.S. Food and Drug Administration /FDA)'nin yaptığı açıklamaya göre Covid-19 aşıSı ancak \%50 veya daha fazla etkin ise o aşıya onay verilecektir. ${ }^{60}$ Çünkü ancak bu oran halahanın gerektirdiği asgari şartı sağlamaktadır. Covid-19 aşısının etki süresinin kısa vadeli olması ise tartışılan diğer bir problemdir. Bu konu ise, yalnızca mevsimsel olarak yaptırılan grip aşısına onay verilmesine kıyas edilerek uygun görülmüştür. ${ }^{61}$

Söz konusu tartışmalar sonucunda günümüz önde gelen halaha otoriteleri Rabbi Moshe Ehrenreich, Rabbi Yosef Carmel, Rabbi Zalman Nechemiah Goldberg, Rabbi Nahum Rabinovitch, ve Rabbi Yisrael Rosen ortak bir bildiriyle dünyadaki doktorların büyük çoğunluğu ve İsrail hükümeti kişinin kesin olarak aşı olması gerektiğine dair karar aldığı takdirde aşı olmanın bir halaha hükmü olacağını duyurmuşlardır. Ortodoks Birliği / Amerika Hahamlar Meclisi'nin, Aralık 2020'de yayınladığı bildiri de Yahudi âlimlerin geçmişteki çiçek aşısı hakkındaki endişelerinin benzer şekilde Covid-19 aşısı için de mevcut olduğunu göstermektedir. Bildiride Covid-19 aşısının hızla geliştirildiği ve iki Covid-19 aşısının yeni bir teknoloji ile üretilen mRna aşısı olmasının endişelere sebep olduğu kabul

58 Ayrıntılı bilgi için bk. Stefan Riedel, "Edward Jenner and the History of Smallpox and Vaccination", Proceedings (Baylor University Medical Center) 18/1 (2005): 21-25.

59 David B. Ruderman, "Some Jewish Responses to Smallpox Prevention in the Late Eighteenth and Early Nineteenth Centuries: A New Perspective on the Modernization of European Jewry", Aleph, 2 (2002): 120; Ha-Rav Abraham Hamburg, Ale Terufa - עלה תרופה (Jerusalem, 1818), 1a-1b. Development and Licensure of Vaccines to Prevent COVID-19 Guidance for Industry (USA: Center for Biologics Evaluation and Research, 2020), 14.

61 Colby, "Covid-19 Vaccine Guidance”, erişim: 20.10.2021, https://web.colby.edu/coronaguidance/files/2020/12/OU-RCA-VaccineGuidance.pdf. 
edilmektedir. Bununla birlikte, Tevrat'ın hayatı koruma yükümlülüğü uyarınca daha fazla hayatı kaybetmeden sağlık otoritelerine güvenerek en hızlı şekilde Covid-19 aşılarının yaptırılması gerektiği kararına varılmıştır. ${ }^{62}$ Rabbi Hershel Schachter, devletin aşıyı zorunlu kılması durumunda "dina de malhuta dina" prensibi gereği Yahudilerin aşı olması gerektiğini ifade etmektedir. Rabbi Asher Weiss ise, modern dönemde aşın olmanın, Talmud'da yer alan pandemi olan bir şehirden kaçma hükmünün yerine geçtiğini belirtmiştir. ${ }^{63}$

\section{4) Aşı Karşıtlı̆̆ı}

Her ne kadar Yahudi grupların aşı olmaya karşı belirgin bir olumlu tavır sergilemesine karşın, Ortodoks Yahudilik içinde aşı karşıtı seslerin çıktığı da görülmektedir. ${ }^{64}$ Bazı gruplar, aşı olmayan pek çok kişinin ileri yaşlara kadar yaşayabildiğini, dolayısıyla aşı olmamanın tehlike oluşturmadığını iddia ederek aşı olmaya karşı çıkmışlardır. Bu iddia, Talmud'da "Üstü açık bir varilden, dokuz kişi içse ve ölmese bile onuncu kişinin ondan içmesi yasaktır" ${ }^{65}$ kuralı gereği isabetli bulunmamıştır. Bu nedenle, dokuz kişi aşılanmasa ve ölmese bile onuncu kişinin aşı olması gerektiği sonucuna ulaşılmıştır. ${ }^{66}$ Aşının muhtemel tehlikelerinden dolayı aşı olmaya karşı çıkanlara ise, yine Talmud'da yer alan ifadelerle cevap verilmektedir. Buna göre; "Tehlike, yasaktan daha ciddi bir durumdur", ${ }^{67}$ dolayısıyla her ne kadar aşının yan etkileri insan için tehlike arz etse de aşı olmama durumunda insanın başına gelebilecek tehlike çok daha büyük olduğundan kişi aşı olmayı tercih etmelidir. ${ }^{68}$ Bununla birlikte modern literatürde Yahudiliğin aşı olmayı yasakladığına dair argümanlar sunulmasa da aşı olmanın zorunlu olup olmadığı konusu tartışılmaya

62 "Covid-19 Vaccine Guidance".

63 Sharon Galper Grossman \& Shamai Grossman, "Halakha Approaches the COVID-19 Vaccine”, Tradition Online, erişim: 22.10.2021, https://traditiononline.org/halakhaapproaches-the-covid-19-vaccine/.

64 Bk. Khitam Muhsen v.dğr., "Risk Factors of Underutilization of Childhood Immunizations in Ultraorthodox Jewish Communities in Israel Despite High Access to Health Care Services", Vaccine 30/12 (2012): 2109-2115; Popper-Giveon \& Keshet, "Non-Vaccination Stage Model (NVST): The Decision-Making Process Among Israeli Ultra-Orthodox Jewish Parents".

65 Babil Talmudu, Avoda Zara, 3ob.

66 Rabbi David Golinkin, "Does Halakhah Require Vaccination Against Dangerous Diseases Such as Measles, Rubella, Polio and Covid-19?", The Schechter Institutes, erişim: 25.10.2021, https://schechter.edu/does-halakhah-require-vaccination/.

67 Babil Talmudu, Hullin, $10 a$.

68 Golinkin, "Does Halakhah Require Vaccination Against Dangerous Diseases Such as Measles, Rubella, Polio and Covid-19?”, 8. 
devam etmektedir. Yehoşua Neuwirth, Hershel Shachter ve David Bleich, salgının azalması ve hastalığa yakalanma riskinin yüksek olmaması sebebiyle ailelerin, çocuklarını aşı yaptırmaları konusunda zorlanmasının doğru olmadığını savunanlardandır. ${ }^{69}$

Yahudilik içinde aşı oranının en düşük olduğu grupların ise UltraOrtodoks Yahudiler içinde olduğu görülmektedir. ${ }^{70}$ İsrail'in toplam nüfusunun yaklaşık \%12'sini oluşturan Ultra-Ortodoks Yahudi cemaati ${ }^{71}$ çeşitli manevi ve siyasi liderlerin rehberliğine tabi olan muhtelif yapı ve alt gruplardan oluşmaktadır. Ultra-Ortodoks Yahudilik kavramı, içerisinde Litvanya kökenli Aşkenaz Yahudilerin oluşturduğu Yeşiva Ortodoksluğu ve mistik karakterli bir hareket olarak ortaya çıkan Hasidi Yahudiliği barındırmaktadır. ${ }^{72}$ Yahudiler arasında en dindar grup olarak kabul edilen Ultra-Ortodoks Yahudiler, Yahudi hukukunun en katı versiyonlarına tavizsiz bağlllıklarıyla bilinmektedirler. Genellikle ahlaki ve flkhi konularda otorite olarak kabul edilen liderlerin tavsiyelerine göre hayatlarını düzenlemekte ve diğer Yahudi gruplarından nispeten izole edilmiş bir şekilde hayatlarını sürdürmektedirler. Bu topluluğun çoğu üyesi ayrı mahallelerde veya kasabalarda yaşamakta, çocuklarını ayrı okullara (yeşiva) göndermekte ve günlük davranışlarını yöneten farklı normlara bağlı kalmaktadır. ${ }^{73}$ İsrail'de Ultra-Ortodoks Yahudi gruplarında yapılan bir araştırmaya göre, aşı karşıtlığının temel sebepleri; ailelerin eğitim durumu, Tanrı'nın doğru olanı (sâlihleri) -aşı olmadan da- koruyacağına dair inanç, aşının hastalıkları önleme gücünün düşük olduğuna inanma ve sağlık otoritelerine güvensizliktir. ${ }^{74}$

Amerika'daki pek çok eyaletteki okullarda, dinî inançlarının aşı olmaya izin vermemesi sebebiyle çocuklarının aşı olmasını istemeyen

69 Elisheva Blas, "One Measly Change: An Unorthodox Approach to Addressing UltraOrthodox Measles Outbreak", Master of Behavioral and Decision Sciences Capstones 5 (2019): 15-16.

70 Lesley Henderson v.dğr., "Perceptions of Childhood Immunization in a Minority Community: Qualitative Study", Journal of the Royal Society of Medicine 101/5 (o1 May1s 2008): 244-251.

71 Gilad Malach \& Lee Cahaner, "2019 Statistical Report on Ultra-Orthodox Society in Israel: Highlights", The Israel Democracy Institute, erişim: 26.10.2021, https://en.idi.org.il/articles/2934.8.

72 Salime Leyla Gürkan, Yahudilik, 6. bs. (İstanbul: İSAM Yayınları, 2017), 100-101.

73 Menachem Friedman, "The Haredi (Ultra-Orthodox) Society-Sources, Trends and Processes", The Jerusalem Institute for Israel Studies Research Series 41 (1991): 1-2; Popper-Giveon \& Keshet, "Non-Vaccination Stage Model (NVST): The DecisionMaking Process Among Israeli Ultra-Orthodox Jewish Parents", 4.

74 Muhsen v.dğr., "Risk Factors of Underutilization of Childhood Immunizations in Ultraorthodox Jewish Communities in Israel Despite High Access to Health Care Services". 
ailelere aşı muafiyeti sağlanmaktadır. Bu muafiyetle aşı olmayan çocuklar, ailelerinin imzalamış oldukları belgeyle okullara gidebilmektedirler. Yahudi okullarında da bazı velilerin bu imzayı vererek çocuklarını okula gönderdikleri bilinmektedir. Bilindiği kadarıyla hiçbir Yahudi otorite, aşı olmanın yasak olduğuna dair bir bildiride bulunmamıştır. Bu nedenle, Yahudi ailelerin dinî sebepleri öne sürerek çocuklarının aşısız şekilde okula devam etmelerini talep etmeleri doğru bulunmamaktadır. ${ }^{75}$

2009 yılında bazı Haredi sağlık uzmanları Lakewood'da bir araya gelerek çocukların aşılanmasını reddeden ailelerle ilgili endişelerini dile getirmişlerdir. Buna karşılık cemaat, önde gelen hahamları aşı konusunda endişeli aileleri ikna edecek açıklama yapmaya çağırmıştır. Bunun üzerine toplanan hahamlar, toplum sağlığını ve çocuklarını ciddi hastalıklardan korumak için ailelerin çocuklarına aşı yaptırmalarını tavsiye etmiştir. Ayrıca bir doktor ya da haham tarafından aksi tavsiye edilmedikçe müdürlerin, aşısız çocukları okullarına almama haklarının bulunduğu ifade edilmiştir. Diğer taraftan 2011 yılında Haredi okullarda ortaya çıkan kabakulak salgına rağmen üç haham (Rabbi Katz, Rabbi Kamenentzky ve Rabbi Malkiel Kotler) Lakewood yeşiva yöneticilerine aşısız çocukların okullara alınmasını talep eden bir mektup kaleme almışlardır. ${ }^{76}$

Geçmişte üretilen aşılara karşı mesafeli olan Ultra-Ortodoks Yahudilerin benzer bir tutumu Covid-19 aşısına karşı da sergiledikleri görülmektedir. New York'taki Harediler üzerinde yapılan bir çalışmaya göre, Covid-19 en çok Haredi ve Hasidi grupları etkilemiştir. Araştırmaya göre Ultra-Ortodoks Yahudilerin yalnızca \%12'si Covid-19 aşısı olmayı kabul edeceğini bildirmiştir. ${ }^{77}$ İsrail Demokrasi Enstitüsü tarafından yapılan araştırma, İsrail'deki Ultra-Ortodoks Yahudilerin, \%90 gibi yüksek bir oranda hahamların otoritesine güvendiklerini ve koronavirüsle mücadelede Rabbani otoritelerin görüşlerine de başvurulmasını istediklerini ortaya koymuştur. Ankete katılanların \%60'ı koronavirüsle ilgili çıkarılan kuralların siyasi amaçlarla çıkarıldığını ve \%81'i sinagoglarda törenlere izin verilmeyip protesto ve gösterilere izin verilmesinin, UltraOrtodokslara karşı ayrımcılık olduğunu düşünmektedir. ${ }^{78}$ Bununla birlikte

75 Bush, "Vaccination in Halakhah and in Practice in the Orthodox Jewish Community", 211.

76 Bush, "Vaccination in Halakhah and in Practice in the Orthodox Jewish Community", 206-210.

77 Ellie R. Carmody v.dğr., "Knowledge and Attitudes Toward Covid-19 and Vaccines Among a New York Haredi-Orthodox Jewish Community", Journal of Community Health 4,6 (2021): 1161-1169.

78 Tamar Hermann \& Or Anabi, "Haredim Trust Rabbis More Than the Health Ministry on COVID-19", The Israel Democracy Institute, erişim: 26.10.2021, https://en.idi.org.il/articles/32950. 
Habad lideri Rabbi Yitshak Yehuda Yaroslavsky, Rabbi Kanievtsky, Rabbi Gershon Edelstein gibi pek çok Haredi haham, aşı olmanın gerekliliğini vurgulayarak tüm Haredilere aşı olmaları yönünde uyarılarda bulunmakta ve hatta aşı olmayanların okullara ve sinagoglara alınmamalarını talep etmektedirler. ${ }^{79}$

\section{Sonuç}

Yahudi geleneğinde insan hayatının korunmasının dinî bir emir olarak kabul edildiği görülmektedir. Tanah'ta ve Rabbani gelenekte, hastalıklardan korunmak için öncelikle Tanrı'ya dua ve ondan bağışlanma istemenin gerekli olduğu belirtilmektedir. Bununla birlikte Rabbani gelenek, kişilere hastalıklardan kaçınmak ve korunmak için üstlerine düşen görevleri yerine getirmeyi de zorunlu kılmaktadır. Buna diğer insanları hastalıklardan korumaya yönelik her türlü önlemin alınması da dâhil edilmektedir. Dolayısıyla Yahudi geleneği doktorlara itimadı ve onların yönergelerine uymayı tavsiye etmektedir. Ayrıca hayatın risk altında olduğu durumlarda dinî yükümlülüklerin askıya alınması gerektiğine de hükmedilmiştir. Bununla birlikte hangi durumların risk olarak kabul edileceği ve karar yetkisinin kimde olduğu konusunda görüş ayrılıkları yaşandığı olmuştur.

Çalışmamızda görüldüğü üzere Covid-19 pandemisi ve aşısı bağlamında Yahudi gruplar ve yetkililer arasında sağllk kurumlarının yönergelerine uyma ve bu doğrultuda hastalığın yayılmaması için gerekli önlemlerin alınması yaygın kanaattir. Ancak daha çok başta Ultra-Ortodoks Yahudiler olmak üzere gerek ibadetleri kisitlayan yasaklara ve gerekse Covid-19 aşısına karşı çıkan grupların var olduğu görülmektedir. Yapılan araştırmalara göre, bu karşı çıkışın farklı nedenlere dayandığı anlaşılmaktadır. Bazıları Tanrı'nın doğru olanı, yani sâlihleri koruyacağı inancıyla ve aşırı önlemlerin Tanrı'ya inancın eksikliğini gösterdiği düşüncesiyle talimatlara uymamaktadır. Ancak Ultra-Ortodoksların salgını tabii bir fenomen olarak değil, işlenen günahlara karşılık Tanrı'nın bir cezası olarak görmesi Modern Ortodoks çevrelerce eleştirilmektedir. Ayrıca, hastalığın dinî hükümleri askıya alacak kadar ciddi olmadığının düşünülmesi, dinî ibadetlere seküler kurumların müdahalesini meşru

79 Shira Hanau, "Major Orthodox Rabbis in Israel Say Everyone 12 and up Should Be Vaccinated", Jewish Telegraphic Agency, erişim: 22.10.2021, https://www.jta.org/quick-reads/major-orthodox-rabbis-in-israel-say-everyone-12and-up-should-be-vaccinated; Israel National News, "Coronavirus Pandemic: Hasidic Groups Ban Unvaccinated, Not Recovered from Synagogues”, erişim: 22.10.2021, https://www.israelnationalnews.com/News/News.aspx/312695. 
bulmama ve Covid-19 aşısının da yeterli güvenirliği kazanmaması diğer nedenler arasında yer almaktadır. İlaveten, koronavirüsün kötü niyetli kişiler tarafından yapay olarak üretildiği ve insanlar üzerinde kontrol sağlama amacı taşıdığı şeklindeki düşünceler de, pandemi nedeniyle uygulamaya konulan farklı yükümlülüklerin reddedilmesine yol açabilmektedir.

\section{Kaynakça}

Açılamalı Kutsal Kitap. İstanbul: Yeni Yaşam Yayınları, 2010.

Blas, Elisheva. "One Measly Change: An Unorthodox Approach to Addressing UltraOrthodox Measles Outbreak". Master of Behavioral and Decision Sciences Capstones 5 (2019): 75.

Bleich, J. David. "Survey of Recent Halakhic Periodical Literature". Tradition: A Journal of Orthodox Jewish Thought 48/2/3 (2015): 41-64.

Bush, Asher. "Vaccination in Halakhah and in Practice in the Orthodox Jewish Community". Hakirah 13 (2012): 185-212.

Carmody, Ellie R. v.dğr. "Knowledge and Attitudes Toward Covid-19 and Vaccines Among a New York Haredi-Orthodox Jewish Community". Journal of Community Health 46 (2021): 1161-1169.

Israel National News. "Coronavirus Pandemic: Hasidic Groups Ban Unvaccinated, Not Recovered from Synagogues". Erişim: 22.10.2021, https://www.israelnationalnews.com/News/News.aspx/312695.

Colby. "Covid-19 Vaccine Guidance”. Erişim: 20.10.2021, https://web.colby.edu/coronaguidance/files/2020/12/OU-RCA-VaccineGuidance.pdf.

Dorff, Elliot N. Matters of Life and Death: A Jewish Approach to Modern Medical Ethics. Illinois: Varda Books, 2004.

Eiger, Akiva v.dğr. Sefer Igrot Sofrim: Mikhteve Kodesh Mi-Ge' one ha-Dor. Viyana, 1929. Friedman, Menachem. "The Haredi (Ultra-Orthodox) Society-Sources, Trends and Processes". The Jerusalem Institute for Israel Studies Research Series 41 (1991): 1-8.

Gilad, Elon. "How Judaism Handled Epidemics Down the Ages". Haaretz, erişim: 21.10.2021, https://www.haaretz.com/science-and-health/.premium-coronavirusepidemic-history-jewish-1.8724141.

Golinkin, Rabbi David. "Does Halakhah Require Vaccination Against Dangerous Diseases Such as Measles, Rubella, Polio and Covid-19?”. The Schechter Institutes, erişim: 25.10.2021, https://schechter.edu/does-halakhah-require-vaccination/.

Golinkin, Rabbi David. "Ten Brief Responsa/Halakhic Reactions to the Corona Crisis". Corona Guidance: Religious Norms for Navigating the COVID-19 Pandemic, erişim: 21.10.2021, https://web.colby.edu/coronaguidance/2020/04/02/golinkin-ten-responsa/.

Greenberg, Rabbi Yitz. "Coronavirus Is A Wake Up Call For Ultra-Orthodox Jews". Jewish Journal, erişim: 22.10.2021, 
https://jewishjournal.com/commentary/opinion/314354/coronavirus-is-awake-up-call-for-ultra-orthodox-jews/.

Grossman, Sharon Galper \& Shamai Grossman. "Halakha Approaches the COVID-19 Vaccine”. Tradition Online, erişim: 22.10.2021, https://traditiononline.org/halakha-approaches-the-covid-19-vaccine/.

Gürkan, Salime Leyla. Yahudilik. 6. bs., İstanbul: İSAM Yayınları, 2017.

Halbfinger, David M. "Virus Soars Among Ultra-Orthodox Jews as Many Flout Israel's Rules". The New York Times, erişim: 20.10.2021, https://www.nytimes.com/2020/03/30/world/middleeast/coronavirus-israelcases-orthodox.html.

Haleem, Abid v.dğr. "Effects of Covid-19 Pandemic in Daily Life". Current Medicine Research and Practice 10/2 (2020): 78-79.

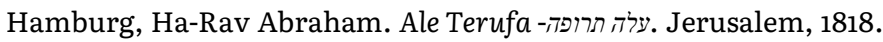

Hanau, Shira. "Hundreds Pack Brooklyn Study Hall and Street for Hasidic Rabbi's Funeral". The Times of Israel, 08.03.2021, https://www.timesofisrael.com/hundreds-pack-brooklyn-study-hall-andstreet-for-hasidic-rabbis-funeral/.

Hanau, Shira. "Major Orthodox Rabbis in Israel Say Everyone 12 and up Should Be Vaccinated". Jewish Telegraphic Agency, erişim: 22.10.2021, https://www.jta.org/quick-reads/major-orthodox-rabbis-in-israel-sayeveryone-12-and-up-should-be-vaccinated.

Heller, Rabbi Joshua. Counting a Minyan via Video Conference. Erişim: 21.10.2021, https://www.rabbinicalassembly.org/sites/default/files/2021-07/heller\%20\%20zoom\%2ominyan.pdf.

Henderson, Lesley v.dğr. "Perceptions of Childhood Immunization in a Minority Community: Qualitative Study". Journal of the Royal Society of Medicine 101/5 (01 Mayıs 2008): 24.4-251, https://doi.org/10.1258/irsm.2008.070363.

Hermann, Tamar \& Or Anabi. "Haredim Trust Rabbis More Than the Health Ministry on COVID-19". The Israel Democracy Institute, erişim: 26.10.2021, https://en.idi.org.il/articles/32950.

Horowitz, Yehoshua. "Hillel”. Encyclopaedia Judaica, ed. Fred Skolnik \& Michael Berenbaum, New York: Thomson Gale, 2007, 9: 108-100.

Ilan, Shahar. "Eli Paley Interviewed in Calcalist, January 28, 2021". The Haredi Institute for Public Affairs, erişim: 22.10.2021, https://machon.org.il/en/elipaley-interviewed-in-calcalist/.

Jacobs, Louis \& David Devoran. "Hermeneutics". Encyclopaedia Judaica, ed. Fred Skolnik \& Michael Berenbaum, New York: Thomson Gale, 2007, c. 9.

Kader, Çiğdem. “Aşı Karşıtlığı: Aşı Kararsızlığı ve Aşı Reddi”. Eskişehir Türk Dünyası Uygulama ve Araştırma Merkezi Halk Sağhğ Dergisi 4/3 (2019): 377-388, https://doi.org/10.35232/estudamhsd.590304.

Kingsley, Patrick. “How Many Funerals Will Come Out of This One?”. The New York Times, erişim: 20.11.2021, nytimes.com/interactive/2021/02/17/world/middleeast/israel-orthodox-jewsharedim.html.

Lipstchitz, Yisrael. Tiferet Yisrael. Çev. Sefaria Community, Vilna, 1913. 
Magid, Shaul. “COVID-19, Haredi Jewry, and 'Magical' Thinking”. Tablet, erişim: 21.10.2021, https://www.tabletmag.com/sections/belief/articles/covid-haredimagical-thinking.

Malach, Gilad \& Lee Cahaner. "2019 Statistical Report on Ultra-Orthodox Society in Israel: Highlights”. The Israel Democracy Institute, erişim: 26.10.2021, https://en.idi.org.il/articles/2934.8.

Meral, Yasin. Yahudi Kaynakları Işığında Yahudilik. İstanbul: Milel ve Nihal Yayınları, 2021.

Moelin, Yaakov Levi. Şe'elot u-Teşuvot Maharil. Krakow, 1881.

Muhsen, Khitam v.dğr. "Risk Factors of Underutilization of Childhood Immunizations in Ultraorthodox Jewish Communities in Israel Despite High Access to Health Care Services". Vaccine 30/12 (2012): 2109-2115.

Nachshoni, Kobi. "Rabbi Kanievsky, a Second Before the Instruction About Holding Studies for Haredim: 'I Haven't Heard About Any Pandemic'”. Ynet, erişim: 20.11.2021, https://www.ynet.co.il/articles/0,734,0,L-5698287,00.html.

Neuschloss, Andrej Simcha. Rabbi Akiba Eger: His Life and Times. Philadelphia: The Dropsie College for Hebrew and Cognate Learning, 1956.

Pirutinsky, Steven v.dğr. "COVID-19, Mental Health, and Religious Coping Among American Orthodox Jews". Journal of Religion and Health 59/5 (2020): 2288-2301.

Popper-Giveon, Ariela \& Yael Keshet. "Non-Vaccination Stage Model (NVST): The Decision-Making Process Among Israeli Ultra-Orthodox Jewish Parents". Health, Mayıs 2021, 1-16.

RAA Igud HaRabbonim. "Rav Yitzchak Yosef: Coronavirus and Cellphones on Shabbos”. Erişim: 20.10.2021, https://rabbinicalalliance.org/2020/03/18/ravyitzchak-yosef-coronavirus-and-cellphones-on-shabbos/.

Reichman, Edward. "Halachic Aspects of Vaccinations". Jewish Action 69/2 (2008): 1014.

Reinherz, Adam. "Rabbi's Pandemic Edicts Save Lives - During the Cholera Crisis of 1831". Pittsburgh Jewish Chronicle, erişim: 30.10.2021,

https://jewishchronicle.timesofisrael.com/rabbis-pandemic-edicts-save-livesduring-the-cholera-crisis-of-1831/.

Riedel, Stefan. "Edward Jenner and the History of Smallpox and Vaccination". Proceedings (Baylor University Medical Center) 18/1 (2005): 21-25.

Ruderman, David B. "Some Jewish Responses to Smallpox Prevention in the Late Eighteenth and Early Nineteenth Centuries: A New Perspective on the Modernization of European Jewry". Aleph 2 (2002): 111-144.

Schternbach, A. \& Y. Eli. "Riots in Mea Shearim: A Girl Was Hurt by a Stun Grenade Thrown by a Policeman." Channel 13 News, erişim: 20.11.2021,

https://13news.co.il/item/news/ domestic/crime-law/crime/jerusalem-corona104,6659/.

Shtern, Marik \& Hani Vayzer. Keeping Our (social) Distance? The Coronavirus Pandemic and the Relationships Between the Various Groups in Jerusalem. Çev. Gilah KahnHoffman, Jerusalem: The Jerusalem Institute for Policy Research, 2021.

Staff, Toi. "Around Half of Israelis Hospitalized with Coronavirus Are UltraOrthodox - Tv". The Times of Israel, erişim: 20.10.2021, 
https://www.timesofisrael.com/around-half-of-israelis-hospitalized-withcoronavirus-are-ultra-orthodox-tv/.

Steinberg, Rabbi Avraham. "The Coronavirus Pandemic: Historical, Medical, and Halakhic Perspectives". Corona Guidance: Religious Norms for Navigating the COVID-19 Pandemic, erişim: 15.10.2021, https://web.colby.edu/coronaguidance/files/2020/06/Coronaviruspandemic_historical-medical-and-halakhic-perspectives_2ndedition_Steinberg.pdf.

Taşpınar, İsmail. "Yahudilik ve Hıristiyanlıkta Tıp”. Sağllk Düşüncesi ve Tıp Kültürü 41 (2016-2017): 36-41.

Trencher, Mark L. "The Orthodox Jewish Community and the Coronavirus: Halacha Grapples with the Pandemic". Contemporary Jewry 41 (2021): 123-139.

U.S. Department of Health and Human Services \& Food and Drug Administration. Development and Licensure of Vaccines to Prevent COVID-19 Guidance for Industry. USA: Center for Biologics Evaluation and Research, 2020.

Central Conference of American Rabbis. "Virtual Minyan in Time of COVID-19 Emergency". Erişim: 21.10.2021, https://www.ccarnet.org/ccar-responsa/5780$2 /$.

Walzer, Michael v.dğr. The Jewish Political Tradition. 4 cilt, New Haven: Yale University Press, 2000.

Williams, Dan \& Maayan Lubell. "More than half Israelis receive both COVID-19 vaccine doses". Reuters, erişim: 27.10.2021, https://www.reuters.com/article/us-health-coronavirus-israel-vaccineidUSKBN2BHOHO. 